\title{
UTLENDINGER I KRIMINOLOGISK FORSKNING: SPØRSMÅLENE BAKENFOR
}

\author{
Noen synspunkter pä innvandrerforskning med utgangspunkt i boka \\ "Utlänningarna och brottsligheten«, rapport 1983:4 fia Brä
}

\section{Av Hedda GifrtSeN}

Ulla-Britt Eriksson og Henrik Tham har redigert en antologi »Utlänningarna och brottsligheten«, som omfatter 10 artikler, og handler om svert forskjellige ting.

Boka synes i hovedsak å falle i to deler. Den ene strekker seg fra s. 1 til 135 og så fra s. 225 og ut. Bortsett fra innledningskapitlet gir denne delen av boka forst og fremst statistiske beskrivelser. Men ikke tilstrekkelig plass til å drøfte mer grunnleggende spørsmål. Når vi blar over fra s. 135 til 136, er vi over i den andre hoveddelen - som har en annen karakter. Gjennom intervjuer făr vi vite noe om hvordan innvandrerungdom ser på sin situasjon. I Julio Ferrers artikkel blir livsstiler som synes meningsløse og destruktive, forklart på overraskende måter. I de to neste artiklene blir ulike sider ved den innvandringen tatt opp og sett i en større sammenheng.

Hvorfor sto ikke disse artiklene forst? Hvorfor er lange og omstendelige statistiske beskrivelser nødvendigvis en innføring til et tema? De kan vare mer villedende enn veiledende. Denne redigeringen setter innimellom leserens tålmodighet på harde prøver, når boka leses fortløpende.

Slik begynte denne artikkelen, som en bokanmeldelse. Men etter hvert gikk det slik at utsagn og avsnitt i boka ble utgangspunkt for å ta opp og drøfte spørsmål som jeg mener er viktige og som bare såvidt eller ikke $\mathrm{i}$ det hele tatt $\mathrm{er}$ tatt opp her. Jeg syntes ikke det var tilstrekkelig bare å peke på hva jeg synes mangler, men ønsket å prøve å bidra til å bringe diskusjonen litt videre. Men dette får til følge at ikke alle artiklene blir kommentert. Dette blir derfor ingen vanlig bokanmeldelse som yter alle artikler og poenger full rettferdighet. Jeg har valgt ut noen temaer.

Denne artikkelen er inndelt i 13 avsnitt som tar opp hvert sitt tema. Det er blitt brokker og biter som ikke er tenkt som noen helhet, men tanker som springer ut av artiklene i boka.

\section{Hvorfor er utlendinger valgt som variabel?}

Dette spørsmålet dukker opp allerede når man leser tittelen. Hvorfor er det interessant å se på koblingen utlendinger og lovbrudd? Hvordan rettferdiggjør 
boka et slikt utsnitt av virkeligheten? Det er selvsagt viktig å undersøke spørsmål man lurer på. Men man bør også ha litt avstand til problemstillingene, vite litt om hvorfor man tar det opp. Jeg synes ikke bidragsyterne gir noe skikkelig svar på hvorfor de har valgt å skrive om utlendinger. Henrik Tham forteller hvordan det ble et tema i Sverige - men ikke hvorfor han mener det er viktig å følge det. Hanns von Hofer gir heller ingen begrunnelse hvorfor utlendinger fortjener spesiell oppmerksomhet når man si noe om lovbrudd i et samfunn. Kanskje det har å gjøre med at tallene allerede er der - og på grunn av nedlagte investeringer fortjener de å brukes? Britt Sveri begrunner utvalget ved å vise til tidligere arbeider hvor utlendinger og nasjonalitet er brukt. Orvar Olsson mener at det finnes flere grunner til å undersøke utenlandske statsborgeres narkotikalovbrudd. Blant annet å finne ut hvilken rolle de faktisk spiller, sammenliknet med det bildet politi og massemedia presenterer. (s. 117) Dette kan det være noe i. Men det spørs vel om kriminalstatistikkens tall gir mulighet for å gå tilstrekkelig grundig til verks.

Når redaktørene og artikkelforfatterne velger å se disse to kategoriene i forhold til hverandre, har det vel å giøre med at vi har inntryk av at det er en ganske utbredt oppfatning i samfunnet at det er en slik sammenheng, at utlendinger begår mer lovbrudd enn svensker (eller nordmenn)." En annen grunn kan være at svensk kriminalstatistikk har vist at utlendinger relativt sett oftere blir registrert for lovbrudd, sammenliknet med svensker. (Men hvorfor valgte statistikerne denne kategorien i første runde??) Med utgangspunkt i denne opplysningen er det flere veier å gå.

Man kan ta som utgangspunkt at kriminalstatistikken gjenspeiler en faktisk forskjell i forekomsten av kriminalitet - og lete etter forklaringer på hvorfor det er slik. Men også innenfor denne rammen er det valgmuligheter.

En annen vei å ta fra kriminalstatistikkens opplysning, er å følge spørsmålene om utlendinger, spesielt visse grupper av utlendinger, lettere blir oppdaget, anmeldt og dømt enn svensker. Det vil si at årsaken til den relative overrepresentasjonen ligger i reaksjonsapparatet mer enn den faktiske fordelin-

1) Men det er likevel ikke sikkert at folk tror det. For én ting er hva vi tror at andre mener, noe annet er hva hver enkelt av oss mener. En svensk undersøkelse »Innvandrarna $\mathrm{i}$ svenskarnas ögon« 1982 har vist at mange tror at andre har en mer negativ innstilling til innvandrere enn det de selv har, og at de gir uttrykk for mer positive holdninger når de er alene enn sammen med andre. (Så kan man undre seg hvorfor og hvordan dette klimaet er skapt. Det ser ut til å være en parallell til dette i noen ungdomsgjenger, hvor den såkalte »flertallsmisforståelsen« rår. (Se f.eks. Hauge 1970.) Den går ut på at ungdommer spesielt litt i utkanten av gjengen tror de må være positive til lovbrudd for å bli akseptert av gjengen. Forskjellen mellom disse to opinionspressene er at det siste foregår innen en liten gruppe og i motsetning til de mer generelle og utbredte verdistandardene som tar avstand fra lovbrudd. Mens de negative holdningene til innvandrere oppleves å være dominerende i den generelle og utbredte kulturen. Det er en viktig forskjell.) 
gen av lovbrudd mellom gruppene. Denne problemstillingen nevnes såvidt $\mathrm{i}$ Henrik Thams innledningsartikkel. Men ingen drøfter dette nærmere.

En tredje vei å gå er å se nærmere på selve antakelsen om en sammenheng mellom utlendinger og lovbrudd. Hvorfor har akkurat utlendinger felt seg ut som en gruppe som synes interessant $\mathrm{i}$ forhold til alle de lovbruddene som blir begått i samfunnet? Hvilke oppfatninger og bilder springer det ut av? Og hvem er det vi tenker på når vi sier »utlending« idenne sammenhengen? Mer generelt sagt: Hvem er det som blir utpekt som fiender, som farlige, som »target groups«, og hva er det som bestemmer dette valget?

Det å trekke ut en bestemt gruppe, rette søkelyset og hjelpe- og kontrolltilltak mot den, vil vel alltid føre til at problemer i akkurat disse gruppene kommer opp i dagen - og noen ganger til at problemer blir produsert. Begge deler leder ofte til at antakelsen som var utgangspunktet for den skjerpete oppmerksomheten og de spesielle tiltakene, blir bekreftet. Bildet av gruppa, ikke bare som annerledes, men også som avvikere, blir opprettholdt og forsterket. Mens andre deler av befolkningen får hvile i fred. Et selvforsterkende system.

Hvem som velges ut som gruppe, avhenger av mange forskjellige ting.

Én ting kan være hva som oppleves som brysomt, som et problem for omgivelsenc. Det må være noen som kan fremstå som representant for gruppa som begår et lovbrudd eller gjør noe annet som blir definert som et problem av omgivelsene. Det kan neppe være noen hvemsomhelst. For at det skal virke, må det nok være en som synes å samle de typiske og »uhyggelige« egenskapene ved gruppa. Men dette forklarer ikke det spranget i tenkingen som en generalisering over til hele gruppa innebærer. Hvor finner vi svaret på slike sprang? Det kan jo ikke vere hos den gruppen som er objekt for fortolkningen. Men i og omkring de som står for den.

Denne gangen gjelder det utlendinger. Men det er ikke noe nytt at kriminologer er opptatt av bestemte grupper. Tidligere er unge trukket fram som spesielt interessante og viktige. Ikke slik at alle unge eller alle utlendinger begår lovbrudd. Men som gruppe fremstår de som mer mistenkelige enn andre.

Hva har unge og utlendinger til felles? Det er ikke så lett å si. Men kanskje våre oppfatninger av dem har noen fellestrekk?

Unge synes å være unndratt samfunnets kontroll, ved at de står utenfor arbeidslivet og den sosiale og økonomiske kontrollen som knytter seg til det. I denne situasjonen synes de også å være mer utsatt for underholdningsindustriens verdier og livsstilidealer. De synes vanskeligere å nå og kontrollere. Utlendinger synes vel også å være løsere knyttet til samfunnet, først og fremst fordi de har fotfeste $\mathrm{i}$ andre kulturer som vi kjenner lite til - bortsett fra enkelte tilfeller av avvik fra våre standarder. Utlendinger synes vel også litt vanskeligere å nå, slik at man er sikker på at de »tilpasser seg«. 
Det er kanskje symptomatisk at begge grupper har vært trukket fram som spesielt betydningsfulle $\mathrm{i}$ forbindelse med brudd på narkotikaloven.

Ingen av dem er sterke grupper. Det fører ikke til store protester eller sympatiaksjoner når noen av myndighetene, først og fremst kontrollørene, holder ekstra øye med dem og det stables på beina ekstratiltak og unntak fra vanlige regler og rutiner.

Begge grupper har kjennetegn som giør dem synlige. Man kan se at personer er unge, omtrent mellom 13 og 23 år, og man kan se omtrent hvor forskjellige personer kommer fra i verden.

Vi kan deles inn i grupper etter noen ytre kjennetegn. Det er jo et ubestridelig faktum at vi tilhører ulike aldersgrupper og forskjellige kjønn, at vi har forskjellige hudfarger og er tildelt ulike nasjonaliteter. Spørsmålet er hva vi gjør med slike forskjeller, hvilke personlige egenskaper som knyttes til slike forskjeller. Det er vel det som er verdt vår oppmerksomhet. Det som skjer så ofte, er at det konstrueres sosiale egenskaper som så knyttes til bestemte ubestridelige biologiske kjennetegn, eller til statsrettslig status. De sosiale konstruksjonene passer så godt inn i den rådende strukturen. Det er ingen tilfeldighet. De er svært effektive til å holde grupper av befolkningen utenfor innflytelse, i så mange slags sammenhenger, på så mange nivåer.

Vi står overfor en dobbelthet. På den ene siden noen ubestridelig objektive kjennetegn. På den andre siden de egenskapene som knyttes til disse kjennetegnene. Noen ganger ser det ut til at skråsikkerheten man kan bruke når man skiller for eksempel aldersgrupper fra hverandre eller kvinner og menn fra hverandre, overføres til uttalelser om de personlige egenskapene.

Når man bruker slike utvendige kjennetegn, som for eksempel utlending eller angir nasjonalitet, er det viktig hele tida å ha denne dobbeltheten i minnet. De objektive kjennetegnene er ikke nøytrale, objektive og uskyldige betegnelser. For de fungerer ikke i et sosialt tomrom, - men gir helt bestemte sosiale ekko i dagens svenske (såvel som norske) samfunn.

Utgangspunktet for artiklene kan gjerne være at »folk« eller massemedia eller statistisk sentralbyrå har sett seg ut utlendinger eller bestemte nasjonalitetsgrupper som en interessant kobling. Og det er også viktig å undersøke om det er spesielle trekk ved ulike gruppers situasjoner som forklarer mengde og former for lovbrudd, om å prøve og å forstå dette. (Slik f.eks. Julio Ferrer gjør det i sin artikkel.) Men det å bli registrert for lovbrudd og definert som kriminell må jo være resultat av minst to parters samhandling. Derfor blir det viktig også å se på alle de valg og avgjørelser hos anmelder, politi, påtalemyndighet og domstoler som bestemmer det endelige resultatet. Det er også viktig å se litt nærmere på 
»common-sense«-definisjoner og -påstander. (Jfr. f.eks. Becker 1973.) Hvis man tar utgangspunkt $\mathrm{i}$ »en aktuell problemstilling « som mange går rundt og mener noe om, må man vende blikket også mot den. Spørsmål man kan stille seg er f.eks.: Hvorfor har dette fremstått som en interessant kategori? For hvem er den interessant? Og så rette søkelyset mot den som velger denne inndelingen, og hvorfor den slår så godt an. Slik at synspunkter på dette, direkte eller indirekte kan komme til uttrykk i teksten.

\section{2. "Nordboere«, "utlendinger og »innvandrere"}

Noen ord om språkbruken. „Utlendinger« står det utenpå boken. Det er også den betegnelsen som brukes i den statistiske beskrivelsen av Hanns von Hofer. Betegnelsen omfatter alle som ikke har svensk statsborgerskap. I og for seg korrekt. Men den er tildekkende i dette tilfellet. For det er nordboere som står for det aller meste av kriminaliteten - også når det gjelder alvorlige lovbrudd og økningen i alvorlige lovbrudd. Det går fram i teksten, men ikke klart nok i sammenfatningene (på s. 15, 16 og.79).

Ikke bare fungerer det tildekkende. Ordet »utlending dreier også oppmerksomheten - bort fra personer i Norden og Nord-Europa og over mot Sør-Europa og andre verdensdeler.

Dette valget av ord gjør at leseren tenker på personer fra andre verdensdeler mens de det først og fremst handler om, er nordboere. Når »utlending byttes ut mot »innvandrer« slik som på s. 16 (se sitat nedenfor) vil leseren ikke lenger være i tvil om hvem det siktes til. Det er iallfall ikke nordboere. (Jfr.: Ole Kristian Hjemdal 1984.)

Beregninger viser riktignok at utlendinger utenom de nordiske land blir registrert for relativt sett flere alvorlige lovbrudd enn svensker, sett på bakgrunn av folketallet. Men det rettferdiggjør vel ikke den språkbruken som er beskrevet ovenfor?

\section{Om å beregne frekvens}

Det er vel også et problem knyttet til dette å beregne frekvens i populasjoner av svært forskjellig størrelse. Sikkerheten i beregningene minker, og muligheten for å generalisere den frekvensen man finner, minker med minkende populasjon. Når den svenske befolkningen er på nesten 8 mill. og de ulike innvandrergruppene av en helt annen størrelsesorden, blir det vet et spørsmål om når det er rimelig å sammenlikne frekvenser. Dette spørsmålet er også tatt opp av Sturla Falck. (NTfK, nr. 3, 1982, s. 129 ff.)

\section{Perspektivet vi velger: Egenskaper ved det å vare innvandrer....}

Henrik Tham skriver et innledningskapittel om forskningens situasjon. Han forteller om hvordan det hele begynte da Pockettidningen R i 1977 pekte på at 
utlendinger sto for en større andel av den registrerte kriminaliteten enn svenskene. Han viser hvordan dette ble tatt opp og offentliggiort da det gjorde og av hvem, og knytter det til erindringer i økonomi og arbeidsliv. Dette er interessant. Men HT slipper dette perspektivet. Og på side 15 er vi over på bokas hovedtema »utländska medborgare i kriminalstatistiken«. Det er her der står. Bokas funn. Resultatet. De håndfaste data »vi alle vil ha«. Først bakgrunnen:

»Siffrorna vederlägger klart vissa överdrivna föreställningar om utlänningars brottslighet. Bl.a. framgår,

- att det är svenskarna själva som står för den absoluta merparten av brottsligheten i landet, och att utländska medborgare 1981 utgjorde 13 procent av de lagförda,

- att lagföringar för stöld och övriga förmögenhetsbrott samt för trafikbrott är vanligast bland utländska medborgare på samma sätt som bland svenskarna, och

- att nordbor utgör mer än hälften av alla lagförda utländska medborgare. (Se även den figur som omedelbart föregår detta avsnitt.)«

Og så det som peker seg ut:

»De utländska medborgarnas brottslighet skall härmed inte bagatelliseras. Ur statistiken kan också utläsas

- att invandrarna lagförs dubbelt så ofta som svenskarna,

- att invandrarna är mer överrepresenterade bland lagförda för allvarligare brott, och

- att de utländska medborgarna utgör så mycket som en femtedel av alla som tas in på kriminalvårdsanstalt. «)

Så er det sagt. Mer behøves ikke sies. Det er dette siste vi husker. Og som avisene slår opp. For eksempel skriver Aftenposten: »Svensk undersøkelse: (Og så med større typer) Kriminelle innvandrere«. (Juni 1983.) Så lenge spørsmålet: Hvor mye lovbrudd begår utlendinger? Begår de relativt mer enn svensker? blir stilt, får vi slike svar.

Så kan vi forklare og vurdere, ta forbehold og begrense gyldigheten. Men kortene er allerede gitt. Det blir vanskelig å holde disse dataene i tømme, noe de følgende avsnittene i denne artikkelen viser. HT drøfter beskrivnings- og forklaringsmodeller. han peker på det problematiske $\mathrm{i}$ å skulle standardisere eller sosiologisere bort de forskjellene $\mathrm{i}$ registrert kriminalitet mellom utlen-

2) Her - og andre steder snakkes det ikke om registrert kriminalitet. Bare kriminalitet. Selv om leseren »vet« at det dreier seg om den som er registrert, er det lett å glemme underveis, og enda lettere å slutte automatisk fra registrert til faktisk kriminalitet - når »registrert« systematisk utelukkes. Redaktørene burde spandert å ta det med. 
dinger og svensker som statistikken viser (s. 18, 19). Jeg er enig i det. Det er grenser for hvor langt man bør gå i å standardisere for forskjeller i tabellenes tendenser. Paradoksalt nok vil slike »bortforklaringer« ofte fungere som en bekreftelse på at hovedtendensen var riktig, hvis de faktorene som brukes til å forklare forskjellene er hektet til gruppen. ${ }^{3)}$ Det blir en form for sosiale egenskaper som bekrefter den opprinnelige konklusjonen. De vil i sin tur igjen lett fungere som form for sosial determinisme for den gruppen det dreier seg om.

Men jeg er ikke enig i HT's valg av løsning. Han vil innskrenke perspektivet og rendyrke »innvandrerfaktoren«:

»Om skillnader kvarstod efter standardisering kunde dessa alltså inte förklaras av att invandrarna oftare är yngre, har ller barn, kortare skoltid, manuella yrken etc. Återstående skillnader i levnadsnivå skulle kunna hänföras till själva invandrarskapet《.

»Intuitivt reagerar man dock mot listan (over standardiseringsfaktorer som er satt opp på s. $18 \mathrm{HG}$ ) och tycker at standardiseringen drivits för långt. Något specifikt $\mathrm{i}$ invandrarskapet har gått förlorat. Det tillhör detta att vara invandrare att typisk sett leva under förhållanden som delvis skiljer sig från svenskarnas.

(s. 19)

\section{5. .... eller trekk ved et mote}

Jeg tror ikke det lar seg gjøre å finne en slik nøkkel som skal forklare »resten«. Det dreier seg ikke om egenskaper ved innvandrerne, verken intelligens, slik man trodde før, eller deres kultur (jfr. Martin Barker, 1981) slik man velger å vinkle det nå, eller sosiale egenskaper slik blant annet »race-relation«-forskningen i England gir så mange eksempler på. (Se f.eks. Jenny Bourne 1980 for en kritisk vurdering av denne forskningens virkninger.)

Det dreier seg om trekk ved et mote mellom innvandrere og det svenske samfunnet (eller norske for den del) - representert ved statlig og kommunalt byråkrati (i Norge vil politiet umiddelbart dukke opp som en relevant gruppe), ulike profesjoner og personer $\mathrm{i}$ mer og mindre uformelle sosiale situasjoner. Innvandrerfaktoren fins ikke. Det er like fåfengt å lete etter den som etter

3) Aubert tok opp dette spørsmålet ut fra sin undersøkelse "Straff og lagdeling« stencil 1963, og drefter det i »Rettens sosiale funksjon« (Oslo 1976 s. 243 ff., s. 248). Han fant først en sammenheng mellom sosial status og domstolers avgjørelser. Siden kontrollerte han for ulike rettsrelevante faktorer som lovbruddstype, tidligere lovbrudd osv. Forskjellene mellom de ulike sosialgruppene minsket. Han sier at kanskje ville forskjellene forsvinne helt hvis han kontrollerte for stadig flere faktorer. Han tror ikke at det ville gå slik. Og uansett er det ikke så viktig. Det hadde ikke rokket ved hovedtendensen i det første han fant. Når det er mulig à redusere forskjellene i reaksjon mellom de ulike sosialgruppene, så betyr det at det som kalles rettsrelevante faktorer, er noyc knyttet til sosial status, og at det leder til det første resultatet. Når forskjellene gradvis blir mindre når man kontrollerer for slike variabler, har det betydning for hvordan man forklarer sammenhengen, ikke om den er der eller ikke. 
formelen for gull. Det å være innvandrer er ikke en egenskap folk har med seg og som så slår ut $\mathrm{i}$ en cller annen form når de får fremmed land under føttene. Innvandrere er forskjellige. De har ulike erfaringer, synspunkter, oppfatninger. De har ulike grunner for å reise og ulike forventninger til oppholdet $\mathrm{i}$ det nye landet. De møter ulike situasjoner. Hvordan skal dette kunne samles i én faktor? Selv regresjonsanalysene vil komme til å lete forgjeves. For selv om de vil ha til felles den opplevelsen at de har reist fra et annet land og de savnene det bringer med seg, så vil denne erfaringen ha ulik betydning. Og det er usikkert om og eventuelt hvordan den vil ha betydning for eventuelle lovbrudd. Hvordan det er å være innvandrer, avhenger av hvordan du møtes i det landet du kommer til. »Innvandrerfaktoren« - det vil si momenter som har betydning for hvordan innvandrere får det - finner vi først og fremst utenfor vår egen stuedør, i de sosiale regler og rutiner og i de maktstrukturene vi til daglig har rundt oss og handler i forhold til. ${ }^{4)}$ Igjen er det spørsmål om hvor vi ønsker og prøver å plassere årsaken til det som skjer.

Jeg tror at istedenfor å innskrenke perspektivet og samle oppmerksomheten mot innvandrere - må vi utvide perspektivet - hvis vi ønsker å prøve å forstå noe av sammenhengen mellom det å være utlending og det å bli registrert for lovbrudd. Og da ikke bare til boligsituasjonen, posisjon på arbeidsmarked, utdanning og økonomisk situasjon og alle slags sosiale egenskaper som »forklarer« lovbrudd. Det er nødvendig å gå videre til selve møtet mellom de ulike personene, posisjonene de står i i forhold til hverandre og grader av makt og myndighet som knytter seg til de ulike posisjonene. Konfliktene mellom enkeltpersonene i lovbruddssituasjonen kan videre forstås ut fra mer generelle samfunnsforhold, slik Leif Lenke og Julio Ferrer gjør i sine artikler i denne boka. Om vi skal prøve å forstå »utlendingers kriminalitet«, må vi fange inn handlingen og konfliktsituasjonen, de mer generelle samfunnsmessige forholdene som konflikten springer ut av - og også hvordan omgivelsene velger å

4) Se f.eks. Eva Olkiewicz (1975, s. 16): »Omgivningen utgör den spegel, där vår identitet bekräftas eller förnekas. .... I sin kontakt med svenskarna finner invandraren ingen överensstämmelse mellan vad han själv uppfatter som sin identitet och den han upplever att omgivningen tilldelar honom. Endast genom kontakt med de nya landsmännen kan invandraren återskapa den känsla av trygghet, kontinuitet og sammanhang i tillvaron som har gått förlorad genom emigrationen. Genom den isolering invandraren har försatts $\mathrm{i}$, har han samtidigt berövats alla möjligheter till en positiv upplevelse av den nya kulturen. Det är detta som man från svensk sida brukar kalla för kulturchock.«

Arne Jartelius sier i sin artikkel »Invandrarnas barn« i »Utlänningarna och brottsligheten« (s. 160): »Låt först följande vara sagt: Min uppfattning är att samhället själv »producerar« - genom den status det ger invandrarna och det värde det tillmäter deras kultur - konflikterna med invandrarna. Någon annan orsak att sätta sin normalitet och sin egenvärdeskänsla i fråga har ịnvandrarna inte än genom den behandling som de utsätts för av majoritetssamhället.« (s. 161, 162.) 
fortolke handlingene. En viktig del av omgivelsene i denne sammenhengen er politi og domstoler. ${ }^{5)}$

\section{Et politi uten betydning?}

Som sagt er politi og domstoler knapt nok nevnt i denne boka. Møtet mellom politi og utlendinger er ikke tatt opp. Heller ikke de ulike partenes posisjoner, makten/avmakten som er knyttet til de ulike posisjonene, forutsetningene for maktposisjonene - og ikke minst virkningene av dem: De ulike partenes fortolkninger av situasjonen og hvilke muligheter de har til å få gjennomslag for sine tolkninger - hvilke handlingsmuligheter de ulike partene står overfor - og virkningene av disse ulikhetene. Ikke noe av dette tas opp. Selv om det er dette filteret som slipper gjennom noen biter av virkeligheten og stenger ute andre og dermed bestemmer hva som skal bli den autoriserte beskrivelsen av lovbrudd og lovovertredere.

Politict har derfor betydning, ikke bare gjennom sine handlinger og de som direkte blir berørt av dem - men også gjennom de bildene som er resultatet av hva de gjør.

Politiet innrømmes riktignok betydning i boka, en mulig betydning (Henrik Tham. s. 22):

"Två huvudtyper av förklaring kan urskiljas. Den ena innebär att överrisken är skenbar och enbart beror på högre sannolikhet att upptäckas, anmälas och lagföras för brott. ...

Hypotesen om selektiv anmälan och behandling inom rättsväsendet till invandrarnas nackdel finns inte systematiskt belyst i Sverige. Självfallet är det viktig att undersöka. Vid sidan av frågan om orsaker om likhet inför lagen där varje fall av ojämlikhet är allvarligt.»

5) Thomas Mathiesen (1984) har tatt opp denne tradisjonen med å trekke ut enkelte faktorer og prøve å finne fram til hvilken betydning de har »isolert sett«. På s. 82 skriver han om den positivistiske samfunnsvitenskapelige tenkemåten og eksperimentets logikk. Han drøfter denne tenkemåten ut fra erfaringer og forskning på to områder, i forhold til massemedia og lov og rett. Og sier: "Det er imidlertid for meg blitt et stort spørsmål om "eksperimentets logikk« er anvendbar i media-forskningen nettopp fordi forholdene, inkludert mediene, som frembringer bestemte holdninger og meninger $i$ befolkningen henger tett sammen $\mathrm{i}$ en stadig gjensidig påvirkning, understøtting og utvikling. Utskillingen av medienes virkning blir dermed kunstig og sosiologisk feilaktig.

Det samme poeng kan fremheves, og er blitt fremhevet, i samband med retten og den sosiologiske utforskningen av den. .... Lovgivningens virkninger eller ikke-virkninger kan altså ikke isoleres forskningsmessig, men må studeres $\mathrm{i}$ sin sammenvevning med omgivelsene:« (s. 83.)

Jeg tror at disse erfaringene og synspunktene har gyldighet også når man skal prøve å si noe om det å være innvandrer. Det må sees i sammenheng med det samfunnet innvandrerne kommer til. 
Og han fortsetter:

»En undersökning av selektionen bör heller inte utesluta den motsatta möjligheten, nämligen att utländska medborgare anmäls och lagförs mindre ofta än svenskarna vid samma brottslighet.«

Men temaet følges ikke opp. Det kunne vært gjort noe mer gjennom problemstillinger eller litteraturhenvisninger.

For eksempel kunne Martti Grönfors' bok »Ethnic Minorities and Deviance: The Relationship between Finnish Gypsies and the Police« (1979) vært nevnt. Han viser at sigøynere har langt større risiko en andre for å bli stoppet. Han nevner også annen litteratur fra USA, Canada, New Zealand som viser de samme resultatene.

Litteratur fra England kunne vært nevnt: Paul Gordon (1983, s. 32) »White Law. Racism and the Police, Courts and Prison«, hvor det i kapitlet om politiet står: »the general picture of policing .. has involved biased use of the law against black people, over-policing of black meetingplaces and events, appalling treatment in police stations, failure to deal properly with complaints and failure to protect black people from racist violence and harassment.«

Eller David J. Smith og Jeremy Gray (1983) som skiller mellom rasistiske og diskriminerende uttalelser på den ene side og handlinger på den andre. De finner at det ikke alltid er noen sammenheng mellom disse to tingene. Men samtidig viser andre deler av denne undersøkelse at: »Black people (but not Asians) are much more likely to be stopped by the police than are white people. ... Police officers tend to make a crude equation between crime and black people ....

Carole F. Willis (1983) viser at »blacks« er 2-3 ganger mer utsatt enn andre for å bli »stopped and searched « av politiet. Den generelle frekvensen av »stop and search« (pr. 1000 menn) var i London $72 \mathrm{og}$ for svarte 149. Forskjellen var enda større i aldersgruppen 16-24 år. Men - ikke alle »stop« ble rapportert - og rapporteringspraksis varierer, så forskjellen kan ha vært enda større.

Maureen Caine og Susan Sadigh (1982) viser at svarte har større risiko for å bli tiltalt for offerløst lovbrudd, det vil si tiltaler som er resultat av »pro-active policing«, sammenlignet med hvite. De viser også at de sakene hvor svarte var involvert, ofte ble oversendt magistrate's court sammenlignet med hvite. Forskjellene er størst blant de yngste.

Sverige er ikke England. Og det er viktige forskjeller mellom det svenske og engelske samfunn - og politi. Men likevel. Disse resultatene burde uroe oss og føre til at vi også ser nærmere på politiet $\mathrm{i}$ egne land.

Men aller mest burde man vel føle uro over sluttproduktet fra det svenske reaksjonsapparatet. Hanns von Hofer viser at andelen utenlandske statsborgere 
øker med lengden av fengselsstraff. Andelen utenlandske statsborgere med en straffetid på 2 år og mer, økte fra ca. 10 til ca. 50\% fra 1964 til 1971, for deretter å avta noe og så holde seg på ca. 35\% fra 1978 til -81. (Diagram 5 og 6). Det kan se ut til at den svenske fangebefolkningen begynner å ligne den vi ser i andre land, hvor etniske minoriteter og spesielt den som utseendemessig kan skilles fra majoritetsbefolkningen, utgjør en uforholdsmessig stor andel.

Tage Erlander har sagt at forestillingen om socialdemokratiets fullkommenhet er den største hindringen mot forbedringer. Kanskje det samme er tilfellet når det gjelder politiopptreden og deres håndtering av saker hvor innvandrere er innblandet? På samme måte som det viste seg å være det i mange, mange år når det gjaldt synet på kvinnemishandling. Vi trodde ikke det fantes i Norge, for det stemte ikke med kartet og idealene.

Jeg tror det er viktig å se nærmere på politiets håndtering av enkeltsaker, deres syn på utlendinger og også hvordan de rettferdiggiør sin opptreden overfor dem. Det har ikke bare betydning for politiet, men ser også ut til å slå inn i samfunnet ellers. Politiets rettferdiggiøring av arrestasjoner og aksjoner mot bestemte grupper (enten de er svarte, pønkere, stoffbrukere eller i Norge: medlem av Folkereisningen mot krig) kan føre til at resten av samfunnet samtykker $\mathrm{i}$ at bestemte politimetoder blir brukt overfor slike »utvalgte« og utdefinerte grupper i samfunnet.

Sosiologen i deler av dennne boka følger en velkjent landevei. Ikke en hvilken som helst landevei, men den som myndighetene har trukket opp. Fordi den følger de vanlig brukte premissene, - retter søkelyset mot enkeltgrupper - og lar det omgivende samfunnet med sine strukturer få stå ubeglodd.

\section{Anonyme krefter og aktiv politikk}

Haluk Soydan skriver om innvandringen i Sverige (s. 31-68). Han starter opp med en kort historikk om folk fra andre land som har innvandret til Sverige tidligere, om svensker som har utvandret til Amerika, og så over til dagens innvandrere. Dette er et vanlig perspektiv. Og også i dette tilfellet virker det som om forfatteren gjerne vil ha oss til å mene att inn- og utvandring, det er en naturlig ting. Det har alltid foregått, folk har alltid krysset grenser. Sant nok, rent faktisk og konkret. Men likevel er det noe som skurrer. Soydan sier: »Redan på 1100-talet etablerade sig tyska köbmän i Sverige. De tyske invandrarna utgjorde en elit tack vara sine kunskaper i internationell handel, sina ekonomiska resurser och internationella kontakter.« (s. 31-32) Det er vel nettopp det. Dagens innvandrere fra Finland, Jugoslavia og Tyrkia utgjør vel ikke nettopp noen »elit« i det svenske samfunnets øyne. 
Inn- og utvandring har alltid foregått. Men de har forskjellig karakter. Disse forskjellene bør ikke underslås.

Det bør de heller ikke når flyttingene skal forklares. Når man skal forklare flyttinger, kan man velge mellom to hovedtyper av forklaringsmodeller. De generelle, ahistoriske modellene - eller forklaringer som er knyttet til den bestemte økonomiske og historiske situasjonen som flyttingen foregår innenfor. HS ser ut til å velge en mer generell forklaringsmodell:

„Sammanfattningsvis kan man säga att den viktigaste orsaken till den moderna svenska invandringen är samspelet mellan en expanderande svensk ekonomi och länder med arbetskraftöverskott.»

Dette er vel eksempel på en "push and pull factor«-modell, hvor anonyme økonomiske krefter sees som de avgjørende.

Men også et mer aktivt element nevnes:

»Även den utomnordiska invandringen ökade genom statsmaktens och andra interessenters aktiva rekryteringspolitik.«

I hvilken grad skal vi se behovet for arbeidskraft i innvandrerland og overskudd på arbeidskraft $\mathrm{i}$ andre land som et (heldig) sammentreff - og $\mathrm{i}$ hvilken grad resultat av en politikk? Situasjonen var der - med »underskudd på arbeidskraft« i noen land og »overskudd på arbeidskraft« i andre. Det første spørsmålet som dukker opp, er hvordan kommer man fram til en slik definisjon om »over- og underskudd« på arbeid? Var det ikke behov for å arbeide og gjøre noe i etterkrigstidas Jugoslavia, Tyrkia, Finland? Hvorfor ble det ikke investert i disse landene på samme måte og i samme grad som for eksempel i Norge som fikk Marshall-hjelp?

Sammenhengen mellom tidligere økonomisk politikk og dagens innvandring blir enda klarere hvis vi ser på England, med sin koloniale fortid og oppretting av politiske grenser og enheter som lettet utbyttingen. England ble som en magnet som trakk til seg verdier, først råvarer, siden arbeidskraften. (Til vinden snudde.)

I hvilken grad kan de nordiske landene sees som noe spesielt? Ikke bare geografisk, men også økonomisk er vi en del av Vest-Europa - med sin koloniale og imperialistiske fortid og så langt det er mulig, utbyttende nåtid.

Det andre spørsmålet er: Hva gjør vi når situasjonen nå engang definert som et la oss si, internasjonalt disekvilibrium av arbeidskraft? Et kapitalistisk blikk lar det neppe gå upåaktet hen. HS forteller om »svenska interessenters aktiva rekryteringspolitik«. Det høres som en nedsnødd virkelighet - og minst like 
forskjønnet. For det som hendte var at svenske (såvel som norske) bedrifter dro til Kontinentet og rekrutterte personer - eller kanskje riktigere sagt, håndplukket den beste arbeidskraftten. Med myndigheters velsignelse. HS viser (s. 34,35 ) hvordan myndighetene oppfattet den første innvandringen som en midlertidig bruk av arbeidskraft. Bruk av ord som gjestearbeider er også et tegn på det.

Det var mulig å definere situasjonen på denne måten: Som »overskudd« av arbeidskraft i noen land og »underskudd« i andre. Situasjonen kan forklares på to forskjellige måter. Enten ut fra generelle modeller hvor årsaken overlates til allment virkende krefter. Eller som et resultat av politisk valg og handlinger. Den første fritar for ansvar. Den andre gjør det vanskelig å unndra seg ansvaret og konsekvensene av valgene.

Valget av forklaringsmåte har betydning.

\section{Syn på innvandring, syn på innvandrere}

Fordi det făr betydning for synet på innvandrere. Ser vi den materielle veksten og dagens standard som et resultat av egen innsats og det å håndtere økonomiske krefter, så fremstår innvandrere som inntrengere som truer våre arbeidsplasser og sosiale goder (vår kultur og identitet). Men hvis vi ser den materielle standarden som resultat av nordvest-europeisk utbytting av andre deler av verden, både i tidligere tider og i dag, så fremstår innvandringen som en følge av den økonomiske politikken som har vært ført. Innvandringen blir en naturlig ting, ikke fordi kjøpmenn fra Tyskland og Skottland har innvandret før - men fordi kapitaleiere i Vest-Europa med de politiske myndigheters godkjenning og støtte trakk til seg verdier fra andre deler av verden og gjorde seg selv til det økonomiske og politiske sentrum i verden. At innvandrere kommer til Vest-Europa i dag, er bare fortsettelsen av historien om vest- europeerne som dro til Afrika og Asia, med glassperler, gevær og bibler.

\section{Innvandringspolitikkens flagskip}

I Haluk Soydans artikkel »Svensk migrationspolitik« får vi vite at »Den nya invandrar- och minoritetspolitiken sammanfattas i form av tre mål«, som är jämlikhet, valfrihet och samverkan. HS kommenterer den og sier at

»tillämpningen av dessa så vackert formulerade målsättningar upplevs otillfredsställande och halvhjärtat på många håll i landet.«

».. man kan fråga sig om opinionsbildare och beslutsfattare som i dagligt tal anslutar sig till dessa nya principer egentligen är helt medvetna om deras verkliga innebörd.« 
Det kunne være interessant å vite noe om hvordan slike formuleringer virker - passiviserende eller aktiviserende og forandrende, og eventuelt under hvilke betingelser. Også som et generelt spørsmål kunne det være interessant å vite noe om hvordan slike store ord fungerer. Kanskje spesielt for Sveriges del, som vel har enda større produksjon av rapporter og målsettinger enn f.eks. Norge.

\section{Hvor skal vi plassere årsaker?}

I avsnittet "migration som problemlösande och problemskapende mekanism« skriver HS:

»Men migration innebär också påfrestningar av olika slag. ... Invandring skapar dessutom nya samhällsfenomen som kulturkonflikter, etniska motsättningar, diskriminering, språkproblem osv. ...

I årene før 2. verdenskrig nektet England å slippe inn jøder fra Kontinentet. De skapte så mye antisemittisme og uro. Så det var best for jødene å slippe å møte slike holdninger i England. (Andrew Sharf 1964.)

Hvor skal vi plassere årsaker til antisemittisme og andre former for diskriminering? Det er vel ikke uten videre riktig eller rimelig å si at årsaken ligger hos de gruppene som fremkaller disse reaksjonene? Det blir vel riktigere å knytte det til de tradisjonene og det kulturelle klimaet og forholdene mellom befolkningsgrupper i det samfunnet som omgir dem, det som gir grunnlaget for generaliseringene.

\section{1. »Vår« kultur og »deres«}

\subsection{De negative forklaringene}

Henrik Tham viser i sin artikkel til Julio Ferrer når han drøfter forklaringer på at utlendinger kanskje begår mindre lovbrudd enn svensker - og tolker ham slik:

»Det finns i invandrarsituationen svårigheter och spänningar som ökar risken för brottslighet. Antagligen finns också faktorer som verkar i motsatt riktning. Julio Ferrer pekar i sitt bidrag på hur invandrare kan känna förakt för alkoholism, narkotikamissbruk, normlöshet och släpphänthet som de tycker sig iaktta i det svenska samhället. Som en reaktion kan de bli moralens väktare. Kanske är också invandrarungdom hårdare kontrollerade av familj och bekanta, vilket delvis skulle motverka den högre risk för brottslighet invandrarställningen medför.«

Jeg tror vi her står overfor et fenomen som er ganske utbredt. Det handler om hvordan vi velger å forklare fenomener - i vår egen kultur og i andre. Når man skal forklare en handling som ansees positivt, og som er begått av personer fra 
andre land, blir det ofte gjort gjennom mer eller mindre negative trekk ved den andre kulturen. Sitatet fra HT's artikkel er et eksempel på det. Jeg møtte det samme da jeg intervjuet dommere i Oslo. De ble blant annet spurt om sitt inntrykk av innvandreres lovbrudd, om omfang og type. Noen av dem uttalte seg også om årsaker til at innvandrere ser ut til å begå lite lovbrudd.

»Dommerene ser først og fremst stengsler. De ser noen kulturelle trekk som hindrer lovbrudd - fordi de hindrer at personer kommer i situasjoner som fører til lovbrudd: kvinner holdes hjemme - og religionen hindrer alkoholbruk. ...

Svarene tyder på at de først og fremst tenket ut fra lovbrudd. Fraver av lovbrudd kommer av fraværd av vanlige årsaker til lovbrudd...

Dommerne ser ingen verdier eller normer som direkte foreskriver for personer $\mathrm{i}$ andre kulturer at de ikke skal begå lovbrudd. De nevner dem iallfall ikke.« (Hedda Giertsen 1982 s. 86)

Hvorfor velger vi å forklare lite kriminalitet på slike måter? Kanskje noe av forklaringen kan ligge $\mathrm{i}$ at vi på forhånd har trukket et skille mellom vår (gode) kultur og de andres (dårlige) kultur? Med en slik oppfatning blir det kanskje umulig å forklare et positivt fenomen, som lite kriminalitet, ut fra positive trekk, fordi kulturen i det store og hele fremstår som »dårlig«. Men det viser seg altså at de kan forklares ut fra negative trekk ved kulturen. Det ser ut til å fungere. For oss.

\subsection{Hvor vi trekker skillelinjer}

Haluk Soydan har skrevet artikkelen »Invandringen till Sverige«. Ett av kapitlene heter »Sverige som flerkulturellt samhälle«. Her tar han også opp dette »att bedöma kulturer«, og problemer som knytter seg til å »Bedöma kulturer inom ramen för ett flerkulturellt land«. Han fortsetter:

»Socialantropologen U. Hannerz har insett den motsättningen och lyfter fram den intrikata frågeställningen med hjälp av några besvärliga (och dessutom aktuella) exempel: hur skall vi bedöma företeelser som aga av barn, kvinnlig omskärelse, vidskeplighet i stället för sjukvård, som alla utgör kulturelement inom ramen för idag i Sverige existerande kulturgrupper?«

Når vi skal drøfte dette, er det vel flere ting det er viktig å holde fra hverandre. Det dreier seg om selve handlingene, hva som virkelig foregår og som vi så får vurdere ut fra de verdiene vi har. ${ }^{6)}$ Det andre spørsmålet er hvordan disse handlingene er knyttet til den kulturen de skjer innenfor, eller

6) For meg vil det i denne sammenhengen bety å ikke akseptere fysisk straff av barn, eller overgrep mot kroppslig integritet, som for eksempel kvinnelig omskjæring. 
deler av denne kulturen. Det tredje spørsmålet er hvordan vi oppfatter denne tilknytning mellom handling og kultur, når det gjelder fenomener $\mathrm{i}$ andre kulturer og i vår egen.

HS nevner "aga av barn och kvinnlig omskärelse« som eksempel på kulturelementer innenfor rammen for kulturgrupper som befinner seg i Sverige i dag. Er dette for generelt sagt? Hvor sterk er tilknytningen mellom slike handlinger og kulturen? Gjelder det alle de personene og gruppene som man kan si tilhører kulturen - eller er det uenighet og diskusjoner om verdier, slik vi ser i vår egen kultur? Kulturer er jo ikke statiske eller helt entydige. Men - noen trekk vil være mer utbredt og gjennomgående i noen kulturer enn andre. Det har også betydning hva som er de offisielle, allment aksepterte holdningene. Dette vil være forskjellig for forskjellige land og kulturer, og det er ofte viktige forskjeller. Men sammenhengen mellom handling og det sosiale og kulturelle miljøet drøftes sjelden - og heller ikke her i denne artikkelen. Det fremstilles nokså enkelt og ukomplisert, uten forsøk på å dokumentere den underforstått entydige og sterke sammenhengen.

La oss se litt nærmere på sammenhengen mellom handling og holdning i vor egen kultur, gjennom ett eksempel: Kvinnemishandling. Nå nevner ikke Hannerz/Soydan det, men det trekkes fram i andre sammenhenger, og jeg tror det er brukbart som en illustrasjon.

Hvis vi skal se kvinnemishandling i forhold til det kulturelle klimaet den skjer innenfor i vårt samfunn, blir det viktig å skille mellom ulike områder. Ett av dem er de offisielle erklæringene, de generelle meningene som går ut på at kvinnemishandling ikke kan aksepteres. Det hører jo ganske rimelig, også ut fra straffelovens paragraf 228, 229 om legemsfornærmelse og legemsbeskadigelse. Så har da også striden stått om hvilke ord som skulle brukes. Det er ikke så lenge siden politiet klassifiserte det som »husbråk« (Strøkken m.fl. 1981), og det ble ansett som et privat mellomværende. Hvis vi fjerner oss litt fra de generelle offisielle erklæringene, men fremdeles holder oss til det offentlige, viser det seg at holdingene ikke lenger er så helt entydige. Den klare forkastningen er ikke lenger fullt så klar. En undersøkelse foretatt av Helsedirektoratet/Oslo helseråd fant at kvinner som var utsatt for mishandling i ekteskapet, $\mathrm{i}$ en del tilfeller ble henvist til psykolog for å bli bedre $\mathrm{i}$ stand til å håndtere situasjonen $\mathrm{i}$ ekteskapet. Det vil si at problemet individualiseres og årsaken knyttes til offeret, til kvinnen. Det var en høyere andel mannlig helsepersonell som valgte denne løsningen fremfor å henvise til familievernkontor eller å gi kvinnen opplysninger omkring skilsmisse.

Økte kunnskaper om kvinnemishandling, gjennom krisesentre, intervjuer, forskningsrapporter har vist at omfanget og karakteren av kvinnemishandling sprenger rammen for en årsaksmodell som bygger på psykologiske særtrekk hos 
noen få utvalgte menn. De fleste av dem som mishandler kvinner, er slett ikke så avvikende. Tvert imot. De er temmelig konforme med visse trekk ved mannsrollen, i sitt syn på kvinner og sin holdning til vold. Kvinnemishandling må forklares ut fra kulturelle trekk, ikke individuelle, avvikende enkeltpersoner. Ikke ut fra trekk ved den offisielle kulturen, men en som er ganske utbredt og ligger like under overflaten,

"Det er forbudt å slå. Men $\mathrm{i}$ vårt samfunn er det fremdeles $\mathrm{i}$ mange miljøer akseptabelt »å sette kona skikkelig på plass« når mannen bedømmer det som rimelig. Massemedia medvirker til å giøre vold til legitim underholdning. I pornografien blir kvinner $\mathrm{i} ø$ øende grad fremstilt som voldsofre som skal gi menn seksuell stimulering. Så lenge vold på denne måten $\mathrm{i}$ vårt samfunn aksepteres $\mathrm{i}$ visse situasjoner, vil etter vår mening mishandling og undertrykking av kvinner oppretholdes.« (Kirsti Malterud og Kari Bjørneboe 1984 s. 745)

Dette var et eksempel på tilknytningen mellom en type handling og kultur i vårt samfunn. Det var ingen sammenheng mellom handlingen og den offisielle kulturen. Men like under fernissen finner vi holdninger som aksepteres eller vil fungere aksepterende overfor denne type handling. Det neste vi kan gjøre, er å se nærmere på hvordan vi vurderer sammenhengen mellom handling og kultur i vårt eget samfunn og i andre - hvor vi velger å trekke skillelinjer. Hva er bakgrunnen for slike valg - hvilke former for hensiktsmessighet styrer dem?

Soydan viser til handlinger som godtas $i$ andre kulturer og forkastes $i$ vår. Han nevner kvinnelig omskjæring, ofte brukt av folk i Nord-Vest-Europa når kulturer skal sammenliknes. Det deler liksom så klart. Gjett hvem som kommer best ut! Vi kunne valgt andre eksempler. Hvilke kulturer har fremmet utvikling av våpenteknologi? I hvilke kulturer har profithensyn en slik legitimitet at det rettferdiggiør markedsføring av gifter som nikotin, alkohol, medisiner med farlige bivirkninger, plantevernmidler som skader personer (og av morsmelktillegg) - uansett hvilke menneskelige skader det fører til? (Markedsføringen drives ikke bare innenfor egen politisk enhet, men også innenfor andre nasjonalstater. I denne sammenhengen veier plutselig kravet om å beskytte nasjonens integritet ingenting.)

Det er neppe noen kulturell tilfeldighet at akkurat kvinnelig omskjæring nevnes, hvis vi skal følge Lars-Henrik Schmidts (1983, s. 41, 42) synspunkter:

»I den moderne vestlige verden er vårt kjønn og vår seksualitet blitt til selve sannheten og hemmeligheten om den enkelte. Den alvorligste og mest ødeleggende krenkelse et menneske kan utsettes for, er overgrep mot kjønnsdelene. Når vi hører om forskjellige omskjeringsritualer $\mathrm{i}$ andre kulturkretser, blir vi fylt av vemmelse og hellig vrede. For oss er slike omskjæringer det samme som at det går på livet løs, 
og at selve det menneskelige har blitt krenket. En slik »negativ identifikasjon« er et velkjent fenomen fra sosialantropologien; det er oss selv som blir sett på gjennom motlyset fra de andre. Når omskjæringene derfor skaper dette ubehaget hos oss, skyldes det at det rører ved vår oppfattelse av det aller helligste, hemmeligheten om oss selv. Vi klarer ikke å se våre egne »omskjæringer« i samme alvorlige lys, slik som fottøyet, hygienen, body-building eller liknende. Det er på tide å spørre om hvorfor. Andre folkeslag aksepterer omskjæring, men kan derimot ikke godta at man fjerner hår fra kroppen, noe som for oss virker helt naturlig.«

I denne artikkelen viser L-HS hvordan vår holdning til kjønn har forandret seg siden 1700-tallet "Fra natur over sunnhet til balanse«. (s. 49) Han viser hvordan vår holdning er et sosialt fenomen, en sosial konstruksjon og sier at hvis

»Man kunne befri kjønnet fra helliggøøringen og fra voldtektens figur såvel som fra skjønnsskjendelsen. Så kunne vi kanskje i stedet begynne å snakke om en allmenn lemlestelse."

Når vi snakker om handlinger i egne og andre kulturer, er det alltid et spørgsmål om hvor vi velger å plassere skillelinjene.

Vi kan enten trekke linjen mellom kulturene, slik at »noen«, det vil si vår egen, fremstår som »den gode« og andres som »dårlige«.

Hvordan har vi klart å opprettholde dette skillet? En av grunnene henger vel sammen med hvordan vi forklarer (bestemte typer) handlinger. Når vi står overfor handlinger i eget samfunn som vi vurderer negativt - hvordan skal vi holde ut med dem - hvordan kan vi forklare dem? Vi har en enkelt håndgrep: De forklares ut fra individuelle årsaker. Voldtekt, kvinnemishandling, barnemishandling forklares med avvikende enkeltpersoner - som så får bære rundt på noen negative trekk ved vår kultur. De blir unntaket som bekrefter regelen. $\mathrm{Og}$ regelen, det er alle oss andre og kulturen. Syndebukken enda en gang. Og årsaken til tilsvarende fenomener i andre kulturer - hvordan forklares så de? Ut fra deres kultur - av og til nærmest som en arvesynd.

Dette er den ene måten å trekke skillelinjer på, mellom kulturer.

Den andre måten er å trekke skillelinjer $\mathrm{i}$ forhold til verdier, slik at vi plasserer handlinger, enten de nå forekommer $\mathrm{i}$ andres eller egen kultur, $\mathrm{i}$ forhold til dem. Det betyr at vi ikke prøver å lage store helhetlige konstruksjoner av verdisett hos andre folk og kalle det kultur, - for så å ta standpunkt til denne konstrukjonen ut fra våre verdier. Men at vi behersker oss, nøyer oss med å se på handlingene som forekommer i eget og andres land og regioner - og så 
vurderer dem ut ifra våre verdier. ${ }^{7)}$ Vi slipper å gi oss i kast med de store og uhåndterlige kulturbegrepene, som aldri fanger inn de viktige variasjonene, forskjeller, opposisjon og enighet. Variasjonene er viktige. De gir mulighet for å samarbeide på tvers av lande- og kulturgrenser, slik at man kan få en svært nødvendig hjelp til å se hva som foregår i egen kultur og også drøfte muligheter og strategier for endring.

\section{Om å overleve i en drabantby}

Den sjette artikkelen i boka »Utlänningarna och brottsligheten« er skrevet av Julio Ferrer og heter »Kulturgränser och gängbildning - exempel från en Stockholmsförort«. Den handler ikke om utlendinger, ser det ut til. Til å begynne med. Men etter hvert viser det seg at den har gjort det hele tiden.

Den starter med insekter. Om hvordan de som er uten utspekulerte angrepsutstyr og skumle gifter, låner farger, mønstre og stillinger fra andre og farlige arter. Mimikry kalles det.

Så over til mennesker - og hvordan vi på forskjellige steder og til forskjellige tider bruker klær og symboler på forskjellige måter for å overleve når verden blir kaotisk og truende. Det var ikke bare britiske soldater dengangen de sloss mot romerne, eller prærieindianerne, eller »gunmen« i det ville vesten som kledde seg ut for å skremme fienden og på denne måten prøvde å øke sin mulighet for å overleve. Det gjør også ungdom i en svensk drabantby i dag.

»De facto är våldsrykten, vapen och dräkter med våldssymboler oftast former av mimikry,« sier Ferrer.

Nå er det ikke noe spesielt for ungdom å presentere seg gjennom klær og symboler. Det gjør vi alle, prøver etter beste evne (og oppskrifter fra moteskaperne) å fremheve bestemte sider ved oss selv, leter etter symboler som vi synes forteller hvem vi er. (Se f.eks. Sven Tito Achen 1984).

Men det å uttrykke seg gjennom symboler ser ut til å ha forskjellig betydning. Én ting er å presentere seg på best mulig måte. En annen ting er å bruke symboler for å overleve. For grupper av ungdom ser det ut til at det siste er

7) I dette tilfellet vil det for meg bety å ta avstand fra, ikke bare kvinnelig omskjæring, men også et kvinneideal og en klesmote som gjennom pinetrange bukser og feilformete sko ødelegger, eller lemlester, deler av kroppen. Og samtidig, gjennom å fremheve kroppsdeler, gjør kvinner til kjønnsobjekter - og preger deres identitet som det. Og gjør det lett å kontrollere dem både samfunnsmessig og individuelt.

Jeg vil ikke gå inn på spørsmålet om »hva som er verst«. Ikke fordi kvinnelig omskjæring og lemlestelse av andre deler av kroppen varierer $\mathrm{i}$ grad og alvorlighet innen hver sine kulturområder. men fordi poenget her er et annet: nemlig å peke på at dette foregår og er mulig fordi kvinners identitet knyttes til disse ulike formene for lemlestelse - og fungerer kontrollerende. 
tilfellet. Noen av eksemplene i Ferrers artikkel tyder på det. Symbolene, handlingene og klesdraktene de tar i bruk, er drastiske, går på tvers, stiller seg direkte i opposisjon til etablerte verdier. Symbolene henter ungdom selvsagt fra de voksnes verden, f.eks. fra voldspornografi og nazismen. Hvorfra ellers?

Hvorfor er det slik? Hvorfor velger de disse symbolene, hvorfor denne motstanden? Det er vel det vi har så vanskelig for å forstå. Vi har kanskje ikke tilstrekkelig redskaper til å skjønne det? Så kaller vi det sosiale problemer, og hekter det til personlighetsutviklingsforstyrrelser, etter hvert til familiedynamikk og det som foregår i de nærmeste omgivelsene. Det har nok noe for seg. Men det spørs om det er helt og fullstendig dekkende.

Ferrer nevner blant annet søking etter identitet (s. 146, 147). Det har andre nevnt før, men så: åpner han vinduer og dører og slipper lys og luft inn i vår sosialdemokratiske tankeverden, slipper til erfaringer fra andre tider og steder:

»Källargångar och skyddsrum, garage och höghustak, torrsoprum, sopnedkastrum, cykel- och barnvagnsrum blir på kvällen och på natten de yngre tonåringarnas domäner i de moderna förorterna.

De vuxnas armé härskar där på dagen. De vuxna besiktigar, byter trasiga och sönderslagna lampor, tömmer sopor och underhåller byggnaderna, men vid mörkrets inbrott kommer en gerilla som med skruvmejslar och andra verktyg forcerar låskolvar och grindar, vänder upp og ned på husen och lämnar efter sig ett obegripligt landskap.«

»Den moderna industristaten har fått ett »osäkert landskap« mitt i sin tätaste bostadsbebyggelse. - Dessa gränsområden utgör ett slags stridszoner, vilket har sin motsvarighet i de flesta länders historia. Det har i synnerhet skett när homogena samhällen genomgått förändringar och splittrats, givit vika för strukturella konflikter, religiösa kriser, hungersnöd eller krigshot.»

»Innebörden är att människorna hittar nischer i ett samhälleligt system som håller på att spricka under trycket av förändringarna. Gänget kännetecknar således områden som präglas av kulturell förvirring och svaghet och frånvaro av social stabilitet och homogenitet.«

Dette åpner for nye dimensjoner. Det er ikke lenger bare snakk om forferdelig ungdom, som bør »fjernes«. Eller skakkjørte enkeltpersoner eller en sosial arv. Mye mer enn et unntak er det snakk om at den situasjonen de opplever er en integrert del av det »svenska folkhemmet«. Ungdommer er ute i oprørt og ukjent farvann. Og dette farvannet er det ikke de som har fått i stand. Men heller ikke dette er så nytt. Det nye må være at Ferrer, gjennom å bringe inn et historisk perspektiv, viser at disse ungdommene ikke er alene i historien. De har sine forfedre, selv om vi ikke kjenner dem. De skal hamle opp med ganske 
svære spørsmål som ikke bare knytter seg til deres enkelte personer, men angår oss alle. Det handler om hva slags samfunn vi har fătt i stand, hvordan vi prioriterer og hvordan vi ønsker å ha det. Og i denne nyorienteringen er det en del ungdom som må ta de tyngste takene. Vi aner noen dramatiske dimensjoner - noen sider ved livet som sosialdemokratiet neppe kan tenke ut noen tiltak mot, som profesjoner neppe kan ordne opp i. Det foregår ting utenfor de institusjonene vi har bygget opp, viktige og alvorlige ting - og vi kaller det sosiale problemer.

Det er vel dette vi har så vanskelig for å gripe med vår solide og utbredte sosialdemokratiske tenkemåte. Vi har ikke skikkelig plass for de dramatiske, tragiske og komiske dimensjoner. Vi trodde kanskje vi avskaffet det da vi innførte respatexen, nylon og folkepensjonen?

Alt dette er ikke nytt. Men vi har kanskje ikke forstått det skikkelig, så lenge vi fortsetter å snakke ut fra symptomteorier, reduserer andres atferd til personlige problemer. Så lenge vi snakker om »vi« og »de«.

Jeg vet ikke om Ferrer vil være enig i alt dette. For han legger også vekt på forholdet til foreldre, og oppdragelse:

"Gänget är en produkt av konkreta inlärda erfarenheter, mål och sociala relationer, ty sociala problem beror ofta på vanart och kan uppfostras bort. Inläringsprocessen spelar den avgörande rollen för gängets utveckling, tillvaro och framtid (Sutherland).«

»- Gängets aktivitet förklaras som tidigare antytts, varken av rasism, diskriminering eller arbetslöshet. Nyckelordet är »fritid«. De pojkar som föräldrarna tog ansvar efter skoldagen hade varken tillfälle eller lust att ägna sig åt bus eller brott."

(s. 150, 151)

Det er som han viser til en forklaring på et nivå (den som knytter seg til stridssoner) - og så bringer inn andre forklaringer (dette med læring) og så hva som skal til (at foreldrene tar ansvaret for barna etter skoletid) som er på et annet nivå. Nå behøver det ikke være noen motsetning mellom forklaringer på ulike nivåer. Men det hadde vært interessant å se hvordan han ser disse forklaringene i forhold til hverandre, hvordan de passer sammen.

Har dette med innvandrere å gjøre? Ja da, både dette og de andre temaene han tar opp. Men både det som sies og måten artikkelen er lagt opp på, viser at innvandrerbarn og unges situasjon eksponerer enda tydeligere vanskelige situasjoner som unge i det svenske samfunnet står overfor.

»Den kulturella mångfalden i det moderna samhället ger upphov till en motsatt typ av stress. [Motsatt det at kulturen formidlet en klar identitet og sosial status til samfunnsmedlemmene (s. 147).] 
Invandrarbarn har särskilt svårt att definiera sin egen status i samhället, eftersom grupperna har blivit allt mindre homogena. - Åtskilliga av de punkare som bar svensk efternamn och hade en svensk moder, visade sig vara födda i samliv eller äktenskap med en icke svensk medborgare.«

Et spørsmål Ferrer ikke tar opp, men som vel bør tas opp er hvordan vi skal forstå disse stridssonene. Er de bakvejer, grøfter langs veikanten, som folk kan la være å ramle nedi hvis de vil? Eller er de »sakens kjerne« - uttrykk for en grunnleggende uro og forandring vi alle kjenner gjennom jordskorpa. Forskjellen er bare at noen havner midt oppi, mens andre klarer å unngå dem. Er stridssonene hovedsak eller unntak?

Ferrer rister søvnen ut av en annen »sannhet« også.

"I den moderna svenska skolan har tabuläggningen av handgripligheter effektivt undanröjt varje förutsättning för att våldet skall kunna reduceras till ett minimum. I länder där handgripligheter är självklara och även i viss mån tillåtna är aggressioner och mobbning minimala, eftersom det skapas en »terrorbalans«.« (s. 140).

Han viser at ungdom har sine grenser for bruk av vold. (Se f.eks. s. 142, 145). Men reguleringen av vold og utprøvingen av grenser blant barn og ungdom er blitt forhindret og stoppet, fordi voksne i sin uforstand og sitt strev med å skape »det gode samfunn« har forbudt vold i skolen. Gjennom sitater fra intervjuer og kommentarer leder han oss fram til denne konklusjonen:

»Paradoxalt nog, kan det tyckas, har pojken hamnat i denna farliga situation (at han kan komme til å bruke karatepinnene og som først og fremst er ment som skremsel fordi han tror at han kan klare å drepe en person med dem) delvis på grund av att han aldrig lärt sig slåss. Han saknar närmare kännedom om våldet, samtidigt som han via $\mathrm{TV}$ och video fått växa upp i en obegripligt våldsam värld.«

Kanskje vi kan se svar på denne ulmende »freden« som består av fravær og fysisk vold, men en stadig angst for den, - i de mange selvforsvarskursene som har dukket opp de siste årene (iallfall i Norge). Det å bli kjent med volden, våre egne krefter og muligheter i en slåsskamp, er trukket i inn i selvforsvarskurs, hvor alt foregår i betryggende former. Dette skaper nok en form for trygghet for de som deltar på kurset. Men samtidig hender det noe annet. Kurset er delt inn i trinn efter ferdighet. Så også på dette området kan du gjøre karriére og bli flink. Vi henter ut trekk fra andre kulturer og gjør det til karriéremuligheter for oss selv. Vi gir det en form vi forstår: konkurranse og karriére. 
Enda ett område er temmet.

Hvorfor er det viktig å bli kjent med volden? Ferrer gir sine svar på det.

Også andre paradokser blir tredd på en linje som gir mening. Ungdommer som stjeler og begår harverk ser opp til politiet. Da de ble tatt, oppga de flere lovbrudd enn politiet kjente til. Dette var ungdom med foreldre fra andre land. Hvordan skal vi forklare dette?

Den vanlige forklaringen er å si at det handler om kulturkonflikt. Ungdom møter ulike oppfatninger, synspunkter og verdier hos foreldre og slekt på den ene siden og blant jevnaldrende og andre de møter i det svenske samfunnet på den andre.

Dette kan ikke bli mer feilaktig, mener Sunil Loona (1984). For hva er kultur? Kultur er former sosiale grupper har for å bruke eller håndtere råvarene i deres sosiale og materielle tilværelse. Man kan ha forskjellig bakgrunn og erfaring å trekke på. Men det avgjørende er likevel den situasjonen vi står i, våre materielle og kulturelle omgivelser. Det er det vi skal forholde oss til, det er det som gir utfordringer og muligheter til løsninger. Det nytter ikke å reprodusere en kultur som hører til i et samfunn langt borte. Innvandrerungdom, såvel som arbeiderklasseungdom utvikler sine verdier og sin måte å overleve på.

Ferrer deler dette perspektivet når han sier:

»Deras normbrott var ett led $\mathrm{i}$ deras utforskande verksamhet $\mathrm{i}$ ett för dem obegripligt samhälle.»

(s. 155, 156)

Ferrer viser hvordan det i ungdommers øyne er uforståelig at noen strever og sliter og tjener penger, mens andre bare kan gå på sosialen og hente dem. $\mathrm{Og}$ ingen gjør noe med deres lovbrudd, selv om sosialmyndighetene holdt øye med dem. Han viser det så tydelig - at det blir nødvendig å tenke seg om, fordi igjen å kunne se det på den vanlige måten.

Mot Ferrers beskrivelse og måte å forstå lovbruddene på, blir sosialarbeiderens symptomteori eller hevnteorier, spinkle saker:

"Sosialarbetare och barnavårdsnämnd tolkade i allmänhet pojkarnas brottsliga upptåg utifrån »symptomteorin« ... En tolkning av förre invandrarchefen Kjell Öberg var att deras brottsliga upptåg var ett slags hämnd på samhället som inte accepterar dem«.

(s. 156.)

Og ikke bare spinkelt. Det er også systemvennlig forklaring som dreier oppmerksomheten mot individet, klienten, og lar omgivelsene $\mathrm{i}$ fred.

Til slutt sier Ferrer at det symbolske voldsinnslaget er blitt mer påtagelig og det virkelige mer sjelden. Han forklarer det med en ny revolt, en reaksjon på tidligere ungdomskultur, »motbilder till hippies och mods« (s. 158), og at den 
nye revolten gjenspeiler en ny moralisme: „Sköt dig själv och visa att du duger«. Denne forklaringen blir litt tynn, synes jeg, i forhold til alle de momentene som er nevnt tidligere i artikkelen. Det hadde vært interessant å sett dem diskutert i forhold til hverandre.

Dette er en viktig artikkel. Den tar oss med til noen av de personene som er bak tallene. Han viser oss hvordan handlinger som måter å kle seg på, bruke symboler på, lovbrudd og hærverk blir forståelig ut fra det samfunnet ungdommer ser rundt seg. Han ser handlinger i forhold til konkrete tiltak og ordninger i det svenske samfunnet. Han tegner opp en langt mer troverdig forståelsesmåte enn sosialarbeiderens symptomteori, »hevnmotiv«forklaringer og forklaringer som brukes andre steder i boka, for eksempel antakelsen om innvandrerfaktoren.

Ferrer gir nye dimensioner til forståelsen av disse ungdommenes situasjon ved å vise oss paralleller $\mathrm{i}$ andre historiske situasjoner.

Mer enn tall tror jeg vi trenger slike alternative forståelsesmåter hvor handlinger blir sett $\mathrm{i}$ forhold til sine omgivelser. Tallene blir lett meningsløse og kan lede galt avsted hvis personer løsrives fra sin sammenheng og vi ikke kjenner særlig mye til situasjonene rundt lovbruddene. Spørsmål i andre artikler i denne boka synes feil stilt i lys av denne artikkelen.

Adresse: Universitetsstipendiat, cand. polit. Hedda Giertsen

Institutt for kriminologi og strafferett

Universitet i Oslo

Karl Johans Gt 47

N-0162 Oslo 1.

\section{LITTERATURLISTE}

Achen, Sven Tito: Kroppen og tøyet. Syn og Segn nr. 2/1984. Oversatt utdrag fra »Kroppens symbolik«. Forl. Rhodos (Danmark) 1983.

Aubert, Vilhelm: Straff og lagdeling. 1963. Stencil.

Aubert, Vilhelm: Rettens sosiale funksjon. Universitetsforlaget, Oslo 1976.

Barker, Martin: The New Racism. Conservatives and the Ideology of the Tribe. Junction Books. London 1981.

Becker, Howard: Outsiders. The Free Press. N. Y. 1973.

Bourne, Jenny: Cheerleaders and ombudsmen: The sociology of race relations in Britain. Race and class XXI, 4, 1980.

Caine, Maureen and Susan Sadigh: Racism, the Police and Community Policing: A Comment on the Scarman Report. Journal of Law and Society vol. 9, No. 1, summer 1982, pp. 82-102. 
Falck, Sturla: Den kriminelle innvandrer - eller »en farlig forskningsmyte«. Nordisk Tidsskrift for Kriminalvidenskab. Nr. 31982.

Giertsen, Hedda: Byrettsdommere og utlendingssaker. Stensil. Oslo 1982.

Gordon, Paul: White Law. Racism and the Police, Courts and Prison. Pluto Press. London 1983.

Grönfors, Martti: Ethnic Minorities and Deviance. The Relationship between Finnish Gypsies and the Police. Univ. of Helsinki. Sociology of Law series. No. 1, 1979.

Hauge, Ragnar: Kriminalitet som ungdomsfenomen. Universitetsforlaget, Oslo 1970.

Hjemdal, Ole Kristian: Innvandrere i massemedia. Inst. f. rettssosiologi. Stensil. 1984.

Innvandrarna i svenskarnas ögon. Delrapport från diskrimineringsutredningen. DsA 1982:16.

Loona, Sunil: Kulturkonflikt - rasisme? Forelesning 6.11.84.

Malterud, Kirsti og Kari Bjorneboe: Kvinnemishandling. En undersøkelse fra almenpraksis. Tidsskrift for Den Norske Lægeforening, nr. 10-11 1984.

Mathiesen, Thomas: Retten i samfunnet. Pax forlag, Oslo 1984.

Olkiewicz, Eva: Invandrares anpassningsstrategier. Info-gruppen Pedagogiske Institutionen, Stockholms Universitet. 1975.

Schmidt, Lars-Henrik: Kjønnets hemmelighet. Kontrast nr. 5/6 1983.

Sharf, Andrew: The British Press and Jews under Nazi Rule. Oxford University Press. London 1964.

Smith, David \& Jeremy Gray: Police and people in London. Policy Studies Institute, London 1983.

Stokken, Anne Marie m.fl.: Politiet i det norske samfunnet. Univ.forlaget Oslo 1981.

Willis, Carole F.: The use, effectiveness and impact of police stop and search powers. Home Office Research and Planning Unit. 1983. 